\title{
BAIXO BEBERIBE: A REPRESA DO VARADOURO E OS NEGROS CANOEIROS - O HIGIENISMO ENTRE O RECIFE E OLINDA
}

Resumo: O artigo aborda a geografia histórica do baixo rio Beberibe, entre os núcleos habitáveis de Recife e Olinda, desde a segunda metade do século XVII até o final do XIX, centrando-se nas ações médico-higienistas junto à represa do Varadouro e ao transporte de canoas d'água. As mortíferas epidemias da época eram associadas ao mangue e à água parada da represa, como também à "sujidade" das embarcações conduzidas por negros. Desvela-se, assim, as campanhas profiláticas frente às epidemias, que engendrou destruições e reconstruções da represa, além de coações junto aos canoeiros. Discorre-se sobre estes aspectos desde a construção da represa em 1685, até sua demolição definitiva em 1856, seguido do arrefecimento no uso das canoas. Neste contexto, revela-se a configuração de um "espaço marginal" no baixo Beberibe, no século XIX, com a construção de objetos higienistas às suas margens hospitais, cemitérios e matadouro.

Palavras-chave: Medicina-higienista. Rio Beberibe. Represa do Varadouro. Negros canoeiros. Recife. Olinda.

\section{BEBERIBE LOW: THE DAM OF THE VARADOURO AND THE BLACK CANOE PEOPLE - THE HYGIENISM BETWEEN THE RECIFE AND OLINDA}

Abstract: The article refers the historical geography of their bass Beberibe river, between in the inhabitable nuclei of the Recife and Olinda, from the second half of the century XVII until the end of the XIX century, focusing on the hygienist medicine actions next to the dam of the Varadouro and to transport of canoes of water. The deadly epidemics of the time were associated to mangroves and the stagnant water of the dam, as well as the "dirt" of the embarkations conducted for blacks. It is revealed, like this, the prophylactic campaigns front the epidemics, that has led to destruction and reconstruction of the dam, in addition restrictions to the canoe men. It is describeds about these aspects from the construction of the dam in 1687, until your definitive demolition in 1856, followed by dilution in the use of the canoes. In this context, is revealed the configuration of a "marginal space" in low Beberibe, in the century XIX, with the construction of hygienists objects to its banks - hospitals, cemiteries and slaughterhouses.

Keywords: Medicine-hygienist. Beberibe river. Dam of the Varadouro. Black canoe people. Recife. Olinda.

\section{BAJO BEBERIBE: LA REPRESA DEL VARADOURO Y LOS NEGROS CANOEROS - EL HIGIENISMO ENTRE EL RECIFE Y OLINDA}

Resumen: El artículo aborda la geografía histórica del bajo río Beberibe, entre los núcleos habitables de Recife y Olinda, desde la segunda mitad del siglo XVII hasta el final del XIX, centrándose en las acciones médico-higienistas junto a la represa del Varadouro y al transporte de canoas de agua. Las mortíferas epidemias de la época eran asociadas al manglar y al agua parada de la represa, así como a la suciedad de las embarcaciones conducidas por negros. Se desvelan, así, las campañas 
profilácticas frente a las epidemias, que engendró destrucciones y reconstrucciones de la represa, además de coacciones junto a los canoeros. Se discuten sobre estos aspectos desde la construcción de la represa en 1685, hasta su demolición definitiva en 1856, seguido del enfriamiento en el uso de las canoas. En este contexto, se revela la configuración de un "espacio marginal" en el bajo Beberibe, en el siglo XIX, con la construcción de objetos higienistas a sus márgenes - hospitales, cementerios y mataderos.

Palabras clave: Medicina-higienista. Río Beberibe. Represa del Varadouro. Negros canoeros. Recife. Olinda.

\section{Meandros iniciais - navegando pela geohistória marginal do baixo Beberibe}

Em 1836, o naturalista inglês Charles Darwin visitou Pernambuco, a bordo do navio Beagle. Após tentar, sem sucesso, adentrar em sobrados do Recife, cidade a qual "detestou" pela "falta de civilidade", rumou em direção à Olinda, varando de canoa o rio Beberibe - "o canal pelo qual fomos e voltamos". Durante o trajeto, relatou o seguinte aspecto sobre os mangues: "floresta em miniatura, das margens lamacentas e gordurosas. O verde brilhante desses arbustos sempre me fez lembrar do mato viçoso de um cemitério; ambos se nutrem das exalações pútridas; um fala da morte que passou, outro, amiúde, da morte que virá" (DARWIN, 1992, p. 166). Já em Olinda, o Pai do Evolucionismo conseguiu penetrar uma casa, seu quintal e hortas, até alcançar uma colina mais distante, onde colheu anotações sobre o quadro natural e social da cidade e entorno. ${ }^{2}$

O relato de Darwin sobre o cenário "pútrido" do manguezal parece sintetizar um préstimo marginal construído sobre o rio Beberibe ao longo da história, em especial no tocante ao seu baixo curso. Embora seu discurso se assente na medicina higienista do século $\mathrm{XIX}^{3}$, as preocupações médicas sobre o Beberibe emanam de um período anterior, ainda no século XVII, quando grassou uma epidemia de febre amarela em

\footnotetext{
2 Recusado em duas casas, Darwin ressaltou não sentir "nenhuma paixão" pelos brasileiros: "terra de escravidão, e, portanto, de aviltamento moral". Revelando preocupações higienistas, descreveu os sítios urbanos do Recife e de Olinda: "O Recife acha-se construído sobre bancos de areia estreitos e baixos, separados um do outro por canais [...] A cidade é por toda parte detestável, as ruas estreitas, mal calçadas e imundas [...] O terreno plano e pantanoso [...] está cercado [...] por um semicírculo de colinas baixas [...] Olinda está situada numa das extremidades dessa crista. [...] mais agradável e mais asseada do que o Recife. [...] $O$ objeto mais curioso que observei [...] foi o recife que forma 0 ancoradouro. Duvido de que em todo mundo haja outra estrutura natural que apresente aspecto tão artificial" (DARWIN, 1992, p. 163-166).

${ }^{3}$ A "medicina higienista" remonta ao pensamento hipocrático, retomado modernamente pelo médico inglês Thomas Syndenham (1624-1689), o qual sugeriu haver uma relação entre certas doenças e o meio natural. Entre os séculos XVIII e XIX, a degradação das condições de vida nas cidades industriais europeias, assoladas por terríveis epidemias, acabou servindo de laboratório para o pensamento higienista, que serviu de base intelectual para uma gestão urbana e econômica para as cidades. As causas dos males estavam nos pântanos produtores dos miasmas; na excessiva aglomeração humana; ventilação e iluminação insuficientes; sujeiras acumuladas nos logradouros públicos; nas péssimas condições de trabalho; e na alimentação inadequada (ARAÚJO, 2007).
} 
Pernambuco. Durante o evento, apontou-se como principal foco da pestilência a represa do Varadouro, em Olinda, em razão de sua água parada, do seu pântano e manguezal circunvizinho, elementos "mortíferos" para as autoridades e a sociedade em si. Também as canoas dos negros, que captavam água na represa e abasteciam as vilas do Recife e de Olinda, eram alvos de constantes reclamos, sofrendo coações, dadas às condições de insalubridade das pequenas embarcações, que, além da água, transportavam materiais e pessoas diversas, como o próprio Darwin testemunhou.

Entre os séculos XVII e XIX, a represa, o pântano de Olinda e as canoas d'água foram focos de acusações e estigmas, denotando uma imagem marginal sobre o baixo Beberibe, que igualmente prestava-se a outros usos e construções marcadas por atividades de "cura ou morte" - "da morte que passou, ou da morte que virá", parafraseando o dizer de Darwin. Eram matadouros, hospitais, espaço de quarentena do tráfico negreiro e cemitérios, que situados às margens do Beberibe acabaram por materializar espaços do higienismo, demarcando uma ampla área de isolamento, reduto de práticas e construções indesejadas, situado para "fora das portas" das cidades.

Parte desta "geohistória marginal" será aqui revisitada, centrando-se em dois dos seus elementos mais singulares e indissociáveis: a controversa represa do Varadouro e os negros canoeiros. À luz destes recortes, desvela-se os imbróglios da represa (suas diversas destruições e reconstruções), as campanhas profiláticas frente às epidemias, as causas da "sujidade" no Beberibe, a ligação íntima dos negros canoeiros e lavadeiras com o rio, a ocupação de mocambeiros nos seus alagados, e a construção de objetos higienistas em seu baixo curso. São vários os aspectos abordados, discorrendo-se sobre estes desde a construção da barragem, no final do século XVII, até à segunda metade do XIX, com o fim da represa e o arrefecimento do uso das canoas.

$\mathrm{Na}$ ótica de Milton Santos (1988), geografar a vida significa apreender as dimensões invisíveis da história, desvelando os controles e dominações espaciais do passado, mas também suas resistências. Com efeito, pretende-se no texto ora apresentado desvendar os meandros marginais do Beberibe, revelando coações sobre a barragem do Varadouro e sobre a atividade dos canoeiros. Nesta geografia 
retrospectiva também são rememoradas tramas de resistência, sobretudo quanto ao universo dos negros ribeirinhos em face ao controle do sistema escravista e às imposições do saber médico. Nos alagados e nos mangues do Beberibe, cativos, livres e libertos foram reconstruindo suas vidas, em meio aos hiatos territoriais outrora existentes para além dos núcleos habitáveis do Recife e de Olinda.

\section{Baixo Beberibe: a represa do Varadouro sob ações profiláticas (séculos XVII- XVIII)}

Na ótica de Maurício de Abreu (1997), o surgimento do pensamento higienista no Brasil remonta ao final do século XVIII, quando, atendendo à solicitação da Câmara do Rio de Janeiro, três médicos elaboraram um relatório contendo as causas da insalubridade na cidade. Contudo, uma campanha profilática já havia ocorrido em Pernambuco, ainda em 1685, quando grassou a primeira epidemia conhecida de febre amarela na Colônia, nas vilas do Recife e de Olinda. Naquele instante, Dom Antônio F. Machado da Silva, o Marquês de Montebelo, governava Pernambuco, quando fora acometido pela pestilência, sendo tratado e curado pelo médico português João Ferreira da Rosa (ARAÚJO, 2007; ROCHA, 1960). Montebelo solicitou ao médico as razões do achaque e as medidas profiláticas para sua prevenção. Daí emanou, em 1691, a "[...] primeira campanha higiênico-sanitária oficialmente posta em prática no Novo Continente" (DUARTE, 1956, p. 158).

Malgrado as divergências entre o Marquês e o Senado de Olinda, então contrário à realização da campanha, houve a execução da cruzada higiênica, instituindo "bandos de saúde" para a fiscalização e aplicação de punições, com prescrição de multas, prisões e açoites para os desobedientes às regras. Dentre as medidas profiláticas, registrou-se a fiscalização dos navios no porto do Recife; o enterro das vítimas da febre amarela em Santo Amaro das Salinas, com fogueira acessa sobre a cova durante três dias; a limpeza das ruas, casas e praias; o aterro dos alagados, pântanos e charcos; e o despejo das imundices domésticas dentro do rio, e nunca nas praias (ARAÚJO, 2007; OUTTES, 1991; ANDRADE, 1969).

A cruzada higiênica, contudo, encontrava um entrave no tocante à controversa barragem do Varadouro, no baixo rio Beberibe, em Olinda, tida como possível causa 
de focos epidêmicos, em razão do pântano da represa, da qualidade imprópria da água parada e do mangue do entorno. No mesmo ano do surto de febre amarela, em 1685 , houve a construção da ponte-represa sobre o dique natural do Varadouro, com dezoito bocas abertas (Figura 01). ${ }^{4} \mathrm{~A}$ barragem continha amplo reservatório, protegido do fluxo da maré, onde havia certa abundância de peixes. A água acumulada abastecia Olinda e complementava a demanda do Recife, provida precariamente por cacimbas e cisternas, quase todas de águas salobras, na então llha de Antônio Vaz (llha de Santo Antônio) (ANDRADE, 1969). A água era transportada por negros canoeiros e comercializada por pretas de ganho, ou transferida à tanques de particulares, e depois vendida à população (MELO, 1992).

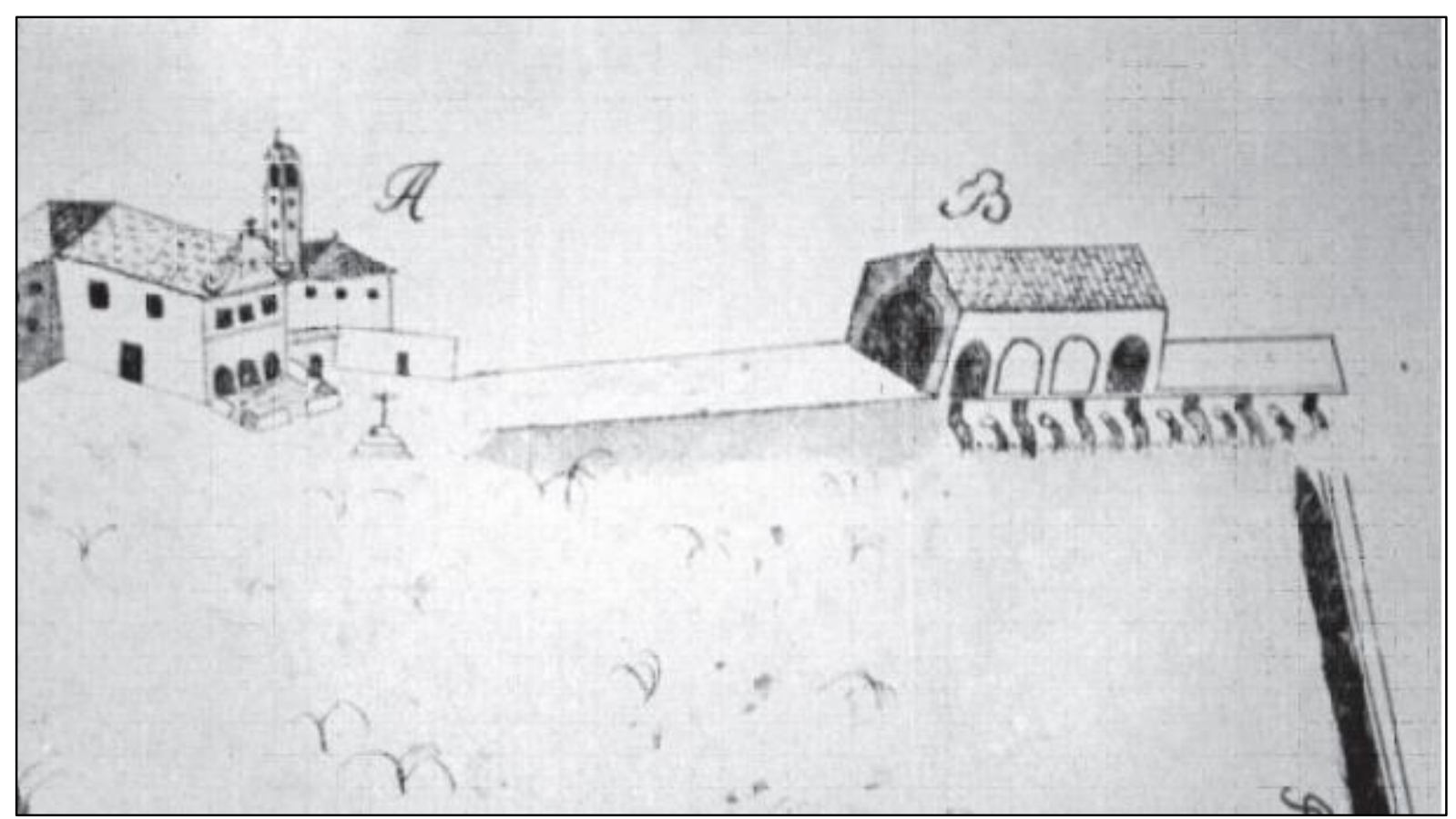

Figura 01: Pormenor cartográfico do século XVII da Vila de Olinda - Arquivo Histórico Ultramarino de Portugal, com indicações para letra "A" (o Convento dos Frades do Desterro Religioso de Santa Teresa); e para letra "B" (a ponte-represa do Varadouro). Na carta notase o desenho das "bicas da barragem", onde se despejava a água doce sobre a salgada, no leito do rio Beberibe. Fonte: Morão, Rosa e Pimenta (1956).

Devido à falta de higiene, diversas críticas surgiram sobre as condições sanitárias da represa, alimentadas pelo sentimento de rivalidade entre os mascates do Recife e os nobres de Olinda. As canoas d'água também eram associadas a sujeira e contaminação, sofrendo constantes coações e reclamos das autoridades e

\footnotetext{
${ }^{4}$ Durante a construção da barragem "[...] ficou feita uma ponte de pedra bem segura, bem larga, e bem vistosa, que, partindo o rio Beberibe, em seu leito, poz-lhe um dique até acima da supperficie das agoas, tanto quanto bastou para dividi-las, sem receio de inundação pela represa, porque logo por dezoito boccas bem abertas, e outras tantos canos compassados Ihe franquearam a sahida, sem que com todo a agoa salgada lhe chegasse para por eles entrar" (GAMA, 1972, p. 213).
} 
sociedade civil. De imediato, os recifenses apontaram como causa da pestilência dos "males" a água "imprópria" do Varadouro. Por essa razão, Montebelo ordenara a destruição da represa com a chegada de $1686 .{ }^{5} \mathrm{Em} 1690$, porém, a Câmara de Olinda elaborou outra planta para reconstrução da controversa barragem, baseando-se no parecer favorável do médico João Ferreira Rosa, o qual também examinara as águas da represa a pedido de Montebelo, eximindo-a da moléstia. Todavia, o Conselho Ultramarino de Portugal negara a reconstrução do paredão, passando a água do Beberibe a ser obtida numa localidade acima da barragem do Varadouro (JUCÁ, 1979; ANDRADE, 1969).

O imbróglio sobre a existência da represa estendera-se ao longo do século XVIII. Em 1711, em pleno apogeu da rivalidade entre o Recife e Olinda, durante a "Guerra dos Mascates" (1709-1711), os moradores da vila colinosa acabaram restaurando mais uma vez a barragem, devido à falta d'água para o consumo e lavagem de roupa. Também mais uma vez, o Conselho proibira sua existência, ordenando a demolição dois anos após a reconstrução. Em 1714, porém, o abastecimento foi retomado após nova restauração da represa, desta vez com regozijado esmero: vinte e quatro bicas. A barragem fora refeita a despeito dos protestos das autoridades e moradores do entorno, insatisfeitos com a inundação de suas lavouras quando das chuvas, e com a dificuldade imposta no transporte de cal e madeira (CAMPOS, 1991; ANDRADE, 1969).

Na primeira metade do século XVIII, o desmatamento das vertentes do Beberibe já se mostrava acelerado, ocasionando frequentes cheias. Em 1744, numa dessas enchentes, o rio abrira outro braço, provocando o desvio definitivo do seu curso, além da diminuição do nível hídrico, que acabou restringindo o fornecimento d'água apenas à vila de Olinda (CAMPOS, 1991). Mesmo com a mudança no curso, os negros aguadeiros continuaram a abastecer as canoas no Beberibe, aproveitando-se quando da maré alta para subi-lo até a represa, próximo ao "Arrombados" (atual bairro Duarte Coelho), lugar onde ocorrera o cataclismo. Um ano após o evento, em 1745, realizouse nova intervenção na represa, ampliando-se o baluarte (GAMA, 1972), revestido de

${ }^{5}$ Conforme consta em resolução régia de 27 de novembro de 1685 (ANDRADE, 1969). 
"belíssima arcada aberta", onde ia-se "[...] para comer, beber e dançar" (GRAHAM, 1992, p. 130), malgrado o imaginário doentio das águas do Beberibe.

Com o passar do tempo, contudo, a penetração da água salgada transformou o lago num verdadeiro paul, desenvolvendo-se vasto manguezal (CORREIA DE ANDRADE, 1987). O processo de decomposição do mangue tornara a água incompatível à pureza desejada. A má qualidade da água também relacionava-se a outros fatores. "A lavagem de roupas tinha o mesmo efeito. Era na povoação de Beberibe, onde se lavava a maior parte das roupas da cidade. Muitas dessas lavadeiras eram inclusive escravas", rememora Carvalho (2010, p. 270). Próximo à represa existia o Porto das Lavadeiras, cuja origem remonta a 1711, tratando-se do mais antigo testemunho da presença de cativas no Tacaruna (COSTA, 1983, v. 5). Outros portos concentravam negros mocambeiros, que também intensificavam a poluição do Beberibe, a exemplo do Veiga, em Santo Amaro, dos Frades ${ }^{6}$, nos Arrombados, e do Porto das Canoas, na freguesia do Fora das Portas, no Recife.

Conforme mencionado, as próprias canoas contribuíam para a qualidade insalubre das águas do Beberibe, sendo alvos também da política higienista. "Além de 'imundas' e 'encharcadas', serviam até de 'banheiro' àqueles que por um vintém o desejavam", recorda Mello (1992, p. 212). No início do século XIX, a viajante inglesa Maria Graham diz ter visto "vinte e sete desses botinhos carregados, levando (água) pelo rio em direção à cidade" (1992, p. 130). Partiam do Varadouro rumo ao Porto das Canoas, ponto de parada de canoeiros e jangadeiros, que no vai-e-vem das águas varavam o Beberibe, comunicando Olinda e o Recife. Os caminhos e vínculos dos canoeiros com a geografia do Beberibe engendrou uma organização social e religiosa bastante representativa, um meio de resistência negra em face às coações do sistema escravocrata e do saber médico-higienista, sobretudo no século XIX.

\section{Do Porto das Canoas ao Varadouro: os negros canoeiros varando o Beberibe}

Ao se estudar a presença histórica do negro em Pernambuco, nota-se a singularidade do rio Beberibe enquanto meio de trabalho, moradia e transporte para homens e mulheres cativos, livres e libertos. O Capibaribe, por sua vez, esteve mais associado aos senhores da terra, dos engenhos de açúcar, e depois, dos

\footnotetext{
${ }^{6}$ De acordo com Mello (1992, p. 208), "[...] a designação de porto do Veiga data de começos do século XIX, época em que o português Manoel Luis da Veiga adquiriu o sítio do Araçá. Porto das Lavadeiras e porto do Frades são designações mais antigas e a segunda tem a ver com o Convento de religiosos terésios instalado nas proximidades desde os fins do século XVII [...]".
} 
aristocráticos sítios de arrabaldes. ${ }^{7}$ Às margens do Beberibe, negras lavavam roupas, pescadores tiravam seus sustentos e canoas de todos os tipos (d'água, condução e varejão) subiam e baixavam o rio, nas tarefas prosaicas de transportar gente, água e material de construção (Figura 02). O tráfego por suas águas representava um monopólio nas comunicações, parecendo "[...] natural a quem tem em mente as conveniências do transporte fluvial entre Olinda e a freguesia de São Frei Pedro Gonçalves (porto do Recife)", recorda Mello (1992, p. 207). Outro caminho utilizado era pela restinga de Olinda (o "istmo"), mas tratava-se de um trajeto penoso pelas areias escaldantes da praia. Mais cômodo era pelo Beberibe.

"O período que vai do último quartel do século XVIII ao fim da primeira metade do XIX constitui a idade de ouro da canoa recifense" (MELLO, 1992, p. 198). Neste entre séculos, "negro e canoeiro chegaram a ser sinônimos na capital pernambucana" (GOMES COSTA, 2013, p. 161). Não obstante a abertura de estradas carroçáveis, e com elas, o desenvolvimento do transporte coletivo terrestre, ainda era possível avistar a atividade dos canoeiros nos últimos decênios do século XIX. Conforme dito, o principal reduto era o Porto das Canoas, transitado por escravos, libertos, pretos e pardos, que construíram formas de organização social ligadas aos meios de trabalho, religião e resistência cultural. Sobre esses grupos, Pereira da Costa (1976) lembrou a existência da irmandade religiosa dos canoeiros, na Rua do Porto, com capela dedicada à Nossa Senhora da Conceição dos Canoeiros, e com festas em homenagem à Conceição, no Recife, e à Nossa Senhora do Rosário, em Olinda. ${ }^{8}$

O pastor Daniel Kidder, por outro lado, quando de passagem pelo Beberibe, rumo a Olinda, descrevera a "hierarquia militar" existente entre os canoeiros, relatando os rituais náuticos existentes no Porto das Canoas. Alguns eram eleitos para os postos de sargento, alferes, tenente, capitão, e até coronel. Não eram, contudo, meramente nominais as suas honras. Em meio as águas, os canoeiros de "patentes" inferiores, quando encontravam oficiais superiores, eram obrigados a saudá-los com uma, duas, três ou quatro varadas na água, com o varejão. O número de varadas obedecia à hierarquia do saudado, o qual retribuía com única varada. Nesta "comunidade aquática", a falta de continência consistia indisciplina sujeita às penalidades. Todavia,

\footnotetext{
${ }^{7}$ Sobre a ocupação histórica às margens do Capibaribe, entre os séculos XVI e XX, dentro do processo de transformação dos engenhos de açúcar aos sítios de arrabaldes, e, depois, aos bairros da cidade do Recife, vide: HALLEY, B. M. Dos moinhos de açúcar aos sítios de arrabaldes: a formação dos bairros continentais na cidade do Recife. Revista de Geografia (UFPE), Recife, n. 3, 2013, p. 58-81.

8 Ver, a propósito dessa identidade de grupo dos canoeiros: CARVALHO, M. J. M. de. Os caminhos do rio: negros canoeiros no Recife na primeira metade do século XIX. Afro-Ásia, Salvador, n. 19/20, 1997, p. 75-93.
} 
caso um canoeiro passasse à frente de um superior, por habilidade ou sorte, estava isento da continência (KIDDER, 1992).

Não é difícil imaginar, no bojo destes contatos, algum tipo de aceno para a fuga de cativo, configurando uma prática de resistência frente ao senhor. Os canoeiros eram violentamente reprimidos e vigiados, devido ao valor a eles conferido, mas também pela mobilidade de sua ocupação, facilitadora de fuga. Ademais, os canoeiros teciam relações com pessoas de lugares distantes: "[...] havia canoeiros que costumavam mudar de nome quando trabalhavam longe da vista do senhor. Isso confundia o dono do escravo e as autoridades na hora da fuga" (CARVALHO, 2010, p. 37). Nas malhas da solidariedade entre os negros, a situação tornava-se mais grave para os senhores quando um canoeiro tramava a fuga de outro cativo por meio das águas do Beberibe. No começo do século XIX, os escravos fugidos rumavam em direção ao Quilombo do Malunguinho, com início nas matas circunvizinhas ao povoado de Beberibe (CARVALHO, 2011).

Distintamente ao Rio de Janeiro, onde comumente lavava-se roupas nos chafarizes, como no regalo do Campo de Santana, no Recife, os açudes, poços e a beira de rios nos arrabaldes eram os locais mais comuns. Por conseguinte, o fluxo das lavadeiras estava intimamente associado ao dos canoeiros, trazendo água e roupa em suas canoas, das freguesias centrais aos arredores, em especial o de Beberibe, conforme já observado. O contato entre as cativas e canoeiros configurava uma relação perigosa para a manutenção da escravidão. Contando com a ajuda dos canoeiros, as escravas tinham uma oportunidade de executarem suas fugas escondidas nos camarotes dos barcos, resguardando a privacidade. Em 1845, um senhor expunha a fuga de um cativo pescador, aproveitando o ensejo para reclamar "[...] aos proprietários de canoas que não permitissem nos camarotes a presença de pretos fugidos, ou pretas, pois já se tirou de uma canoa uma preta da mesma casa" (MELLO, 1992, p. 78).

É fácil imaginar o quanto o rio Beberibe favorecia o negro também neste sentido. O canoeiro era o melhor conhecedor daquelas águas navegáveis, mas de geografia bastante irregular e traiçoeira. Não à toa, era preciso algum treino e especialização para o seu exercício. Era necessário conhecer às aguas a serem percorridas, seus 
meandros, o fundo irregular, as camboas, bancos de areia, o fluxo da maré, o planctum, além de um conjunto de saberes e habilidades para o manuseio da vara, remos e velame (CARVALHO, 2010). Na centúria do oitocentos, ainda havia muito mangue nas margens, alargando-se rio adentro, até após a represa do Varadouro esta sim, um imenso pântano. Devido à correnteza e à presença do mangue, a água do Beberibe diminuía, favorecendo o uso da vara, em recusa ao remo. Em pé, "os negros possantes manobravam sozinhos suas próprias embarcações" (KIDDER, 1992, p. 158), usando o molejo da cintura para se equilibrar. Evidentemente, outras formas de canoas existiam, de maior calado, com remadores em cada lado (MELLO, 1992).

Dependendo do contexto, a profissão de canoeiro também relacionava-se a outras atividades do senhor, em especial as situadas às margens do rio. "Foi assim também com o angolano Manoel. Quando fugiu, era "canoeiro e caiador", dois ofícios aparentemente difíceis de conciliar, se não levarmos em conta que as olarias e os empreiteiros de obras levavam tijolos pelo rio" (CARVALHO, 2010, p. 32). Desse modo, não havia porque não treinar o escravo nos dois ofícios, como forma de elevar a renda do senhorio. A soma de atividades também corroborava para o acúmulo de sujeira nas canoas, as quais sofriam frequentes coações da Câmara de Olinda, que exigia caixões e toneis d'água "bem limpos por dentro" e bem fechados, para evitar a contaminação e a mistura da água doce com a água salgada. ${ }^{9}$

\footnotetext{
9 “[...] em 1837, quando as canoas d'água já tinham uma história quase tricentenária, a Câmara de Olinda, ainda se via na obrigação de aprovar posturas que coagissem os canoeiros a trazerem suas embarcações, caixões e tonéis "bem limpos por dentro", sendo que caixões e tonéis deviam ser escrupulosamente tampados. Também se previa a punição dos canoeiros que vendessem água salobra" (MELLO, 1992, p. 211).
} 


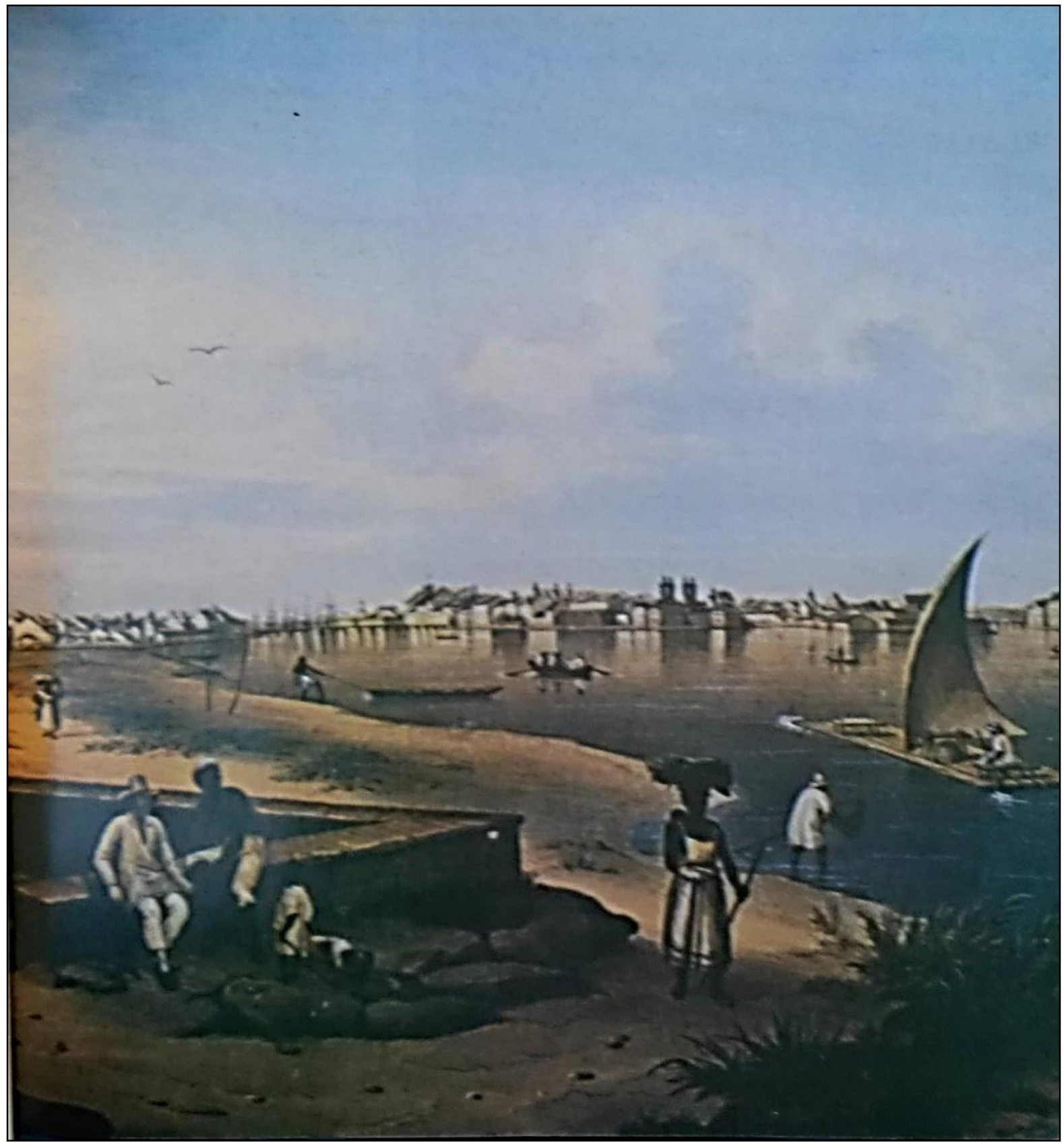

Figura 02: Canoeiros, jangadeiros, pescadores e lavadeiras no rio Beberibe - perspectiva do Forte do Brum, no Istmo de Olinda. Na margem esquerda do rio, negros canoeiros e jangadeiros, e duas negras lavadeiras, afora um negro pescador, e outro sentado no baluarte; ao fundo, na bacia de Santo Amaro, o encontro do Beberibe e Capibaribe, avistando-se o casario de Santo Antônio e da Boa Vista, ao centro e à direita, e o bairro do Recife, à esquerda. Cromolitografia de 1847, por J. Baunsdorf de Dresden. Fonte: Dantas Silva (1998).

No início do século XIX, as más condições das canoas também foram anotadas pelo viajante Henry Koster (1942), tratando-as como embarcações "sujas e 
descuidadas". O Carapuceiro também queixava-se da situação, achando "lastimável" o Recife consumir sua água "[...] em nojentas canoas, as quais andam à discrição dos escravos". ${ }^{10}$ Outras formas de "sujidade" igualmente foram pensadas por Marcus de Carvalho. Na sua ótica, curiosa era a dependência dos senhores dos sobrados aos negros canoeiros. "Quanta água sujada, cuspida e até urinada por negro mais afoito não deve ter sido bebida pelos donos de gente que habitavam a cidade" (CARVALHO, 2010, p. 30), presume o historiador.

De qualquer modo, a maior insalubridade da água do Beberibe resultara do aumento dos ribeirinhos às margens do rio, sobretudo a partir da terceira década do século XIX. As águas tornaram-se mais túrbidas, revelando uma qualidade indesejada na altura da ponte-represa do Varadouro (Figura 03). Naquele instante, as preocupações médico-higienistas cresciam no Recife, com a criação das "posturas municipais"11, calcadas na prevenção dos indivíduos sãos e no uso adequado dos espaços da cidade. O medo se fazia presente frente aos "temíveis miasmas" e às mortíferas epidemias. Em 1856, houve um surto de cólera-morbo em Pernambuco, e, mais uma vez, apontara-se a represa de Olinda como foco da pestilência, além de suas práticas ribeirinhas associadas - canoagem, lavagem de roupa e a própria mocambaria. Exigia-se, assim, sua demolição em definitivo, substituindo o uso das canoas d'água por outras técnicas modernas de captação do manancial controladas por companhias de abastecimento.

\section{0 fim da barragem e das canoas: o baixo Beberibe entre mocambos e construções médico-higienistas (século XIX)}

A partir da terceira década do século XIX, com o crescimento urbano do Recife, houve a maior abertura de estradas suburbanas, facilitando o acesso aos arredores mais distantes, sobretudo com o desenvolvimento dos transportes terrestres. Por conseguinte, também tornava-se mais cômodo o abastecimento d'água a partir do açude do Monteiro (bacia do Capibaribe), cuja qualidade superava a de Olinda. Afora isso, as águas do Beberibe enfrentavam o frequente estorvo dos arrombamentos,

\footnotetext{
10 O Carapuceiro. Recife, edição de 16/08/1839 (apud CARVALHO, 2010).

11 No Brasil imperial, as práticas higienistas associadas ao poder do Estado consolidaram-se a partir da criação das câmaras municipais em cada vila e cidade. A Lei de $1^{\circ}$ de outubro de 1828 regularizou as câmaras, devendo cada uma elaborar e aplicar "posturas municipais" (ou "posturas policiais"), calcadas em reger o cotidiano das populações. No Recife, as posturas foram criadas em 1831, determinando em outras medidas, o controle e higienização das ruas da cidade (ARAÚJO, 2007; OUTTES, 1991).
} 
dificultando a captação do manancial ${ }^{12}$. Pelas aberturas, as águas escapavam, deixando praticamente seca a maior parte do pântano de Olinda.

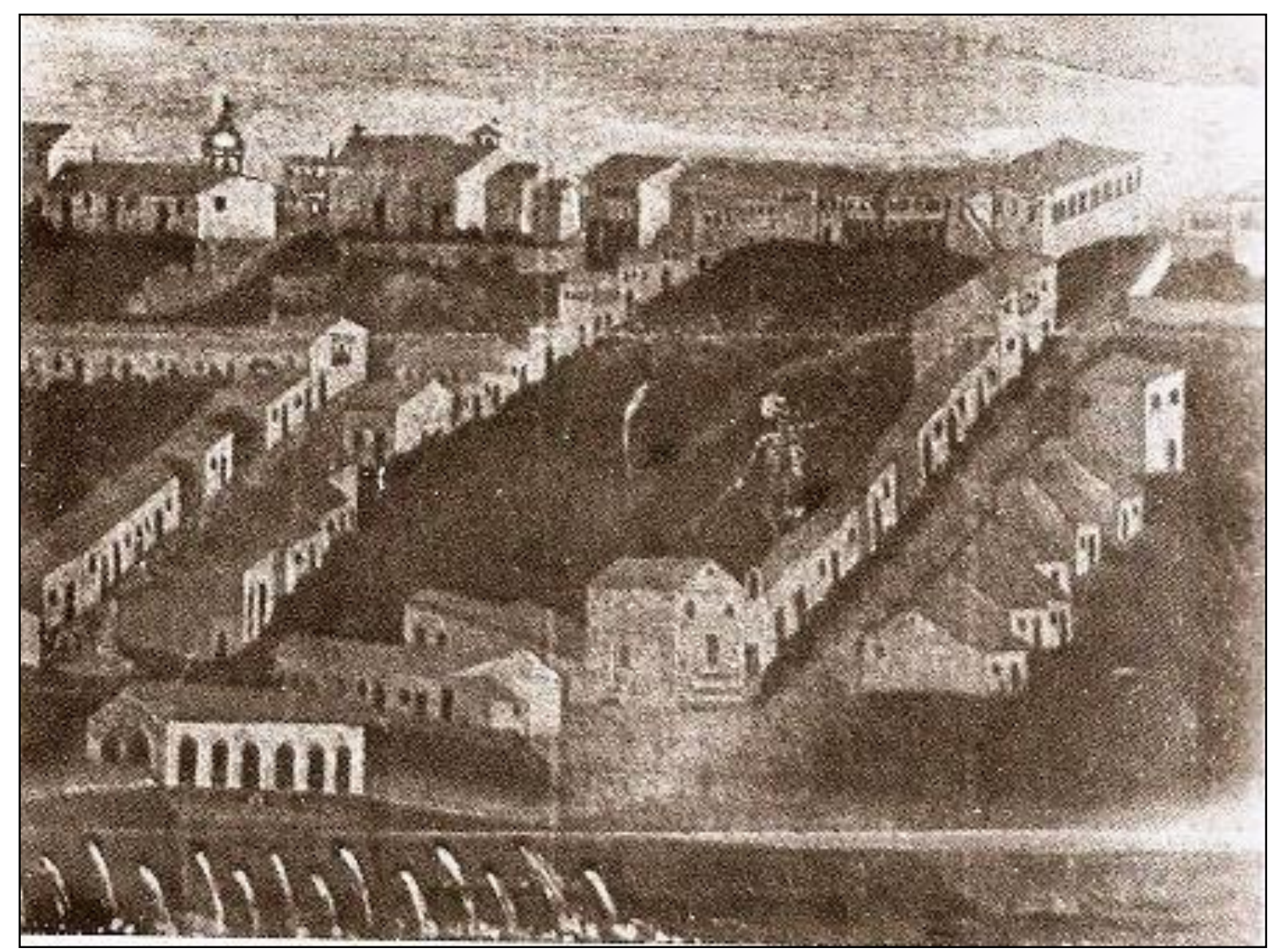

Figura 03: A ponte-represa do Varadouro na entrada de Olinda, em 1830. Na gravura notase o desenho das "bicas da barragem", onde se despejava a água doce sobre a salgada, no leito do Beberibe, além da arcada sobre a ponte aberta nas laterais. Vide também as ladeiras do sítio histórico, as casas e seus amplos quintais. Próximo à represa, a lgreja de São Sebastião construída em 1686, em homenagem às graças alcançadas durante o surto de febre amarela em Pernambuco.

Fonte: Arquivo da Pinacoteca de Igarassu (s/tombo).

Em meio a esse cenário desolador, os negros se viam obrigados a buscar água na camboa dos "Arrombados", enchendo precariamente suas canoas por meio de "canecas". Mas em vão eram seus esforços. Quase sempre a água captada mostravase suja e salobra, especialmente nos períodos da maré muito alta, quando as águas

\footnotetext{
${ }^{12}$ No ano de 1838, "o rio rompera o aterro contíguo a Duarte Coelho. A cidade de Olinda ficou ela própria sem água durante pelo menos seis meses. A cheia de junho de 1842 causou novo arrombo entre a povoação e o Convento de Santa Tereza: um furo de 15 braças por 2 de fundo", registra Mello (1992, p. 212).
} 
salgadas adentravam no pântano (MELLO, 1992) ${ }^{13}$. Em 1843, o médico-higienista Joaquim Serpa comentara as dificuldades em se conseguir água de boa qualidade na barragem de Olinda, durante os anos mais secos de verão: "é necessário que os pretos das canoas d'água, nus, e dentro do pântano junto às bicas, revolvam a água [...] recebendo-se em vez de água potável, água lamacenta"14.

Mesmo com a insuficiência da captação e má qualidade de sua água, o Beberibe continuou a abastecer Olinda e o Recife, mas por via institucionalizada. Em 1838, o então Governador da Província, Francisco do Rêgo Barros, o Conde da Boa Vista, autorizou a contratação de engenheiros para a criação de uma companhia de abastecimento de água potável para o Recife. No mesmo ano fundou-se a Companhia do Beberibe, estipulando a captação na represa de Olinda. Contudo, devido à má qualidade do serviço, outros projetos também foram propostos ${ }^{15}$. Em 1841, o plano dos engenheiros Niemeyer e Bellegarde fora aprovado, com a água retirada no açude do Prata (bacia do Capibaribe), em Dois Irmãos, de melhor qualidade hídrica (COSTA, 1983 , v. 10). No tocante a Olinda, vários outros projetos surgiram, mas nenhum logrou êxito. Somente em 1870 regularizou-se um serviço, sob a condução da Companhia de Santa Teresa. Em 1872, a empresa fixou um chafariz no Varadouro, com a água captada no Cumbe (bairro Aguazinha), nas adjacências do arrabalde de Beberibe (CAMPOS, 1991) ${ }^{16}$.

Conforme ocorreu no século XVII, os serviços regulares de abastecimento d'água se tornaram urgentes na centúria oitocentista, em razão dos mortíferos surtos epidêmicos. Em fins de 1855 e começo de 1856, um surto de cólera-morbo advindo da Europa deixou um saldo trágico de 3.338 óbitos no Recife (OUTTES, 1991), tendo "[...] os foros do mais temível flagelo da Província" (ANDRADE, 1986, p. 18). Dada a

\footnotetext{
13 Informações descritas por Evaldo Cabral de Mello (1992), a partir dos registros realizados pelo engenheiro Milet em relatório de sua autoria: "Tapamento do arrombado de Santa Teresa", 27 de junho de 1842, Obras Públicas, 1842, APP.

14 Trecho citado do livro Topographia da Cidade do Recife, de Joaquim Jeronymo Serpa. (apud Annaes da Medicina Pernambucana, 1977, p. 77).

15 Entre 1894 e 1900, a Companhia do Beberibe chegou a causar grave doença aos moradores do Recife, acometidos de cólica intestinal, prisão de ventre e vômitos. Aventaram-se várias hipóteses sobre o mal, chegando-se à suspeita de saturnismo (FREITAS, 1940). Constataram forte presença de sais de chumbo na água, decorrente do baixo grau "hidrotimétrico" do líquido. Eram muito doces as águas da empresa, com baixa presença de calcário, o que acabou corroendo as canalizações de ferro e chumbo, depositando sais metálicos nas águas (OUTTES, 1991). Em 1912, os serviços da empresa foram transferidos para o Governo do Estado, para Diretoria de Viação e Obras Públicas, e, depois, à Comissão de Saneamento (JUCÁ, 1979).

${ }^{16}$ Fundada no Recife por Claudino Coelho Leal, a Companhia de Santa Teresa realizou suas atividades até 1933, passando seus serviços à municipalidade através do Serviço de Água e Luz de Olinda SALO. Em 1971, com a criação da Companhia Pernambucana de Saneamento - COMPESA, o abastecimento d'água do Estado de Pernambuco ficou sobre a responsabilidade deste órgão (CABRAL, 2004; CAMPOS, 1991).
} 
calamidade, o Conselho Geral de Salubridade estabeleceu um cordão de isolamento para a cidade e para outros lugares de Pernambuco. "Os navios provenientes de portos infectados ou suspeitos deveriam ficar de quarentena, fora da barra e do ancoradouro. Os doentes [...] deveriam ser recolhidos ao hospital da llha do Nogueira" (OUTTES, 1991, p. 26), no extremo Sul do Recife. No extremo Norte, o Conselho ordenara a destruição definitiva da barragem do Varadouro, como forma de eliminar o lendário foco epidêmico associado à água parada e ao pântano de Olinda, zonas de contaminação e putrefação, segundo o discurso higienista.

A represa fora substituída por uma extensa ponte de ferro, em 1856, pondo fim a uma história de três séculos (COSTA, 1983, v. 4). Com as águas concentradas no leito do Beberibe, estabelecera-se a drenagem do pântano de Olinda, aproveitando as terras para atividades agrícolas. Paulatinamente, populações pobres, em sua maioria negros libertos, foram se deslocando dos núcleos habitáveis rumo às áreas do pântano, onde ergueram mocambos, criando vínculos e reconstruindo seus meios de moradia, trabalho e cultura nos mangues do Beberibe. Processava-se, assim, a ocupação daquelas terras periféricas, cuja legitimação do seu aforamento já tinha sido sentenciada ainda em 1710, através do chamado Livro Geral de Foros. Neste documento ficou clara a intenção da Câmara de Olinda: reservar aos mais desprovidos de recursos aquele espaço irregular menos produtivo, marcado por áreas alagadiças. ${ }^{17}$

A demolição da represa do Varadouro, em meados do século XIX, efetivou o desejo antigo, ainda que de forma dispersa. Além das populações pobres deslocadas dos centros do Recife e Olinda, também migraram rumo às terras do baixo Beberibe os flagelados das secas nordestinas e os ex-cativos dos engenhos de açúcar da Zona da Mata. Na verdade, eles rumaram em busca dos alagados, erguendo seus casebres

\footnotetext{
17 A elevação do Recife à condição de vila, em 1710, acentuou divergências entre os mascates e os nobres de Olinda, suscitando uma série de medidas. Uma destas era a ocupação do baixo Beberibe, como forma de assegurar o território por parte da Câmara de Olinda, a partir da legitimação do Livro Geral de Foros, de 1537, referente às doações da Capitania Duartina. O documento demarcou o aforamento de quatorze sítios (do número 109 a 122), abrangendo o Pântano, Salinas, Capins e Lagoas do Concelho, atuais bairros do Varadouro, Vila Popular, Fosforita, Peixinhos, Santa Tereza, Jardim Brasil, Sítio Novo, Salgadinho, Campo Grande, Hipódromo, Encruzilhada, Torreão, Espinheiro, Rosarinho, Ponto de Parada, e partes do Fundão, Água Fria, Tamarineira, Arruda, Beberibe e Sapucaia (AGRA, 1996). O Foral de Olinda revelou uma intencionalidade já na época do donatário Duarte Coelho: delimitar os espaços de produção, circulação e exclusão, para colonizadores e moradores. Aos primeiros foram doadas sesmarias, terra agricultável, própria à economia açucareira; aos moradores restaram as áreas mais improdutivas, alagados e manguezais, aforadas pela Câmara, como o baixo Beberibe. Para ter o domínio útil da terra, as populações pobres tinham que pagar o "foro" através da coleta de crustáceos para alimentação de escravos, e da extração de madeiras nos mangues para construção de casas e consumo dos curtumes. "De resto, não se aproveitavam para mais nada" (SILVA, 2000, p. 28/29) o espaço do baixo Beberibe.
} 
de barro, folhas de flandres e palhas de coqueiros, na mistura incerta de terra e de água do estuário comum dos rios Capibaribe e Beberibe. O contingente maltrapilho avançou em direção ao manguezal, sobretudo a partir do afrouxamento da escravidão, que resultara num expressivo aumento de pessoas livres. Em 1872, 88\% da população da capital pernambucana compunha-se por indivíduos livres e libertos, contra $73,6 \%$ em 1842 , e $40,7 \%$ em $1827 .{ }^{18}$

O baixo Beberibe consolidou-se como um vetor periférico de ocupação territorial para as populações mais desprovidas de recursos, que aproveitaram os hiatos espaciais para se fixarem nos arredores das cidades. Entre o final do século XIX e começo do XX, a ocupação de suas terras estava associada ao "esgalhamento Norte da expansão tentacular do Recife" (MELO, 1978), concentrado às margens do Beberibe e de estradas adjacentes, como a de Luís do Rego, também chamada Estrada de Olinda, delineada a partir do aterro de Santo Amaro, conforme atesta-se na Planta da Cidade do Recife e seus Arrabaldes, de 1876 (Figura 04) ${ }^{19}$. A estrada possibilitou o deslocamento mais acelerado entre o Recife e Olinda, sobrepujando em importância a Estrada de Belém (MELLO, 1992). A via também arrefeceu o tráfego de canoas no Beberibe, sobretudo após o advento dos trens das "maxambombas", em 1871, com a inauguração da linha férrea para Olinda (SETTE, 1981).

Com a expansão do Recife, os mocambeiros foram se fixando nos alagados e sítios próximos à essas estradas e linhas de trem. Ergueram suas habitações em meio ao lamaçal do Beberibe, batendo o solo frouxo do manguezal, onde também coletavam caranguejos, aratus, ostras e sururus. Também "matavam a fome" nos quintais do entorno, repletos de jambos, cocos, goiabas, frutas-pães, cajus e mangas (CASTRO, 1968). Completavam o "ganha pão" nos sobrados do Recife, ocupando serviços outrora feitos por cativos: cozinhar, lavar, engomar, olhar as crianças, encher as tinas da casa nos chafarizes, pentear as senhoras, esvaziar os "tigres" e limpar as escarradeiras (ARAÚJO, 2007). Nos espaços públicos, trabalhavam como quitandeiras, ambulantes e engraxates. Outros estavam nos matadouros, fábricas,

\footnotetext{
${ }^{18}$ Sobre dados e recenseamentos da escravatura no Recife, vide: CARVALHO, M. J. M. de. Liberdade - rotinas e rupturas do escravismo no Recife, 1822-1850. Recife: Editora Universitária, 2010.

${ }^{19}$ A Planta da Cidade do Recife e de seus Arredores, de 1876, de F. H. Carls, evidencia a ocupação nas duas margens da Estrada de Olinda, com a presença de cemitérios e hospitais, em meio aos aterros, ilhotas, alagados e mangues da geografia local. Também revela a ocupação de mocambos, nas proximidades da estrada referida e às margens do Beberibe e afluentes, como o rio Água Fria. Na área correspondente ao antigo pântano da represa do Varadouro, observa-se um amplo manguezal, alguns tufos de matas e aldeias de mocambos mais isoladas, denotando uma ocupação ainda recente, frente à demolição da barragem vinte anos antes, em 1856.
} 
padarias e curtumes, inclusive nas unidades existentes entre o Recife e Olinda (HALLEY, 2017).

Sobre estes objetos, faz-se mister ressaltar que o saber médico-higienista não somente realizou campanhas profiláticas no baixo Beberibe, também corporificou suas margens com construções consideradas insalubres, nocivas à saúde pública, como forma de distanciar e/ou isolar do "contágio" a população citadina, em especial os moradores das freguesias centrais do Recife. De Santo Amaro das Salinas até Peixinhos, efetivara-se um esquadrinhamento higienista durante o século XIX, com a construção de hospitais, curtume, matadouro, fábrica e cemitérios, ao longo das estradas de Olinda e de São Benedito, que corroboraram mais e mais para a ideia de isolamento do baixo Beberibe, como também para a contaminação de suas águas (SILVA, 2000). Circunvizinhos a essas construções, estavam os mocambos, sítios de coqueiros e vilas de pescadores, moradias dos mais desvalidos de outrora, erguidas nos mangues e alagados ou em áreas mais secas pouco valorizadas, conforme observa-se no Pormenor da ocupação do baixo Beberibe entre as cidades do Recife e de Olinda no final do século XIX - trecho entre o bairro do Recife e o Varadouro (Figura 04).

Em tempos mais remotos, o baixo Beberibe já se prestava como refúgio de objetos e práticas indesejadas, de risco aos indivíduos sãos. A partir do século XVII, a margem direita serviu de espaço de quarentena do tráfico negreiro e de enterro das vítimas da febre amarela, em Santo Amaro das Salinas; a margem esquerda era utilizada como cemitério de escravos pagãos, no istmo de Olinda, próximo à Cruz do Patrão, situada entre o rio e Oceano Atlântico (HALLEY, 2017; CARVALHO, 2010). Logo, as preocupações ou necessidades médicas sobre o baixo Beberibe não se restringiram apenas à existência da controversa represa de Olinda, do pântano e das canoas, elas também se centravam nos seus espaços ermos, como as salinas e o istmo, locais estratégicos para isolar possíveis focos pestilentos desde os primeiros séculos de colonização. 


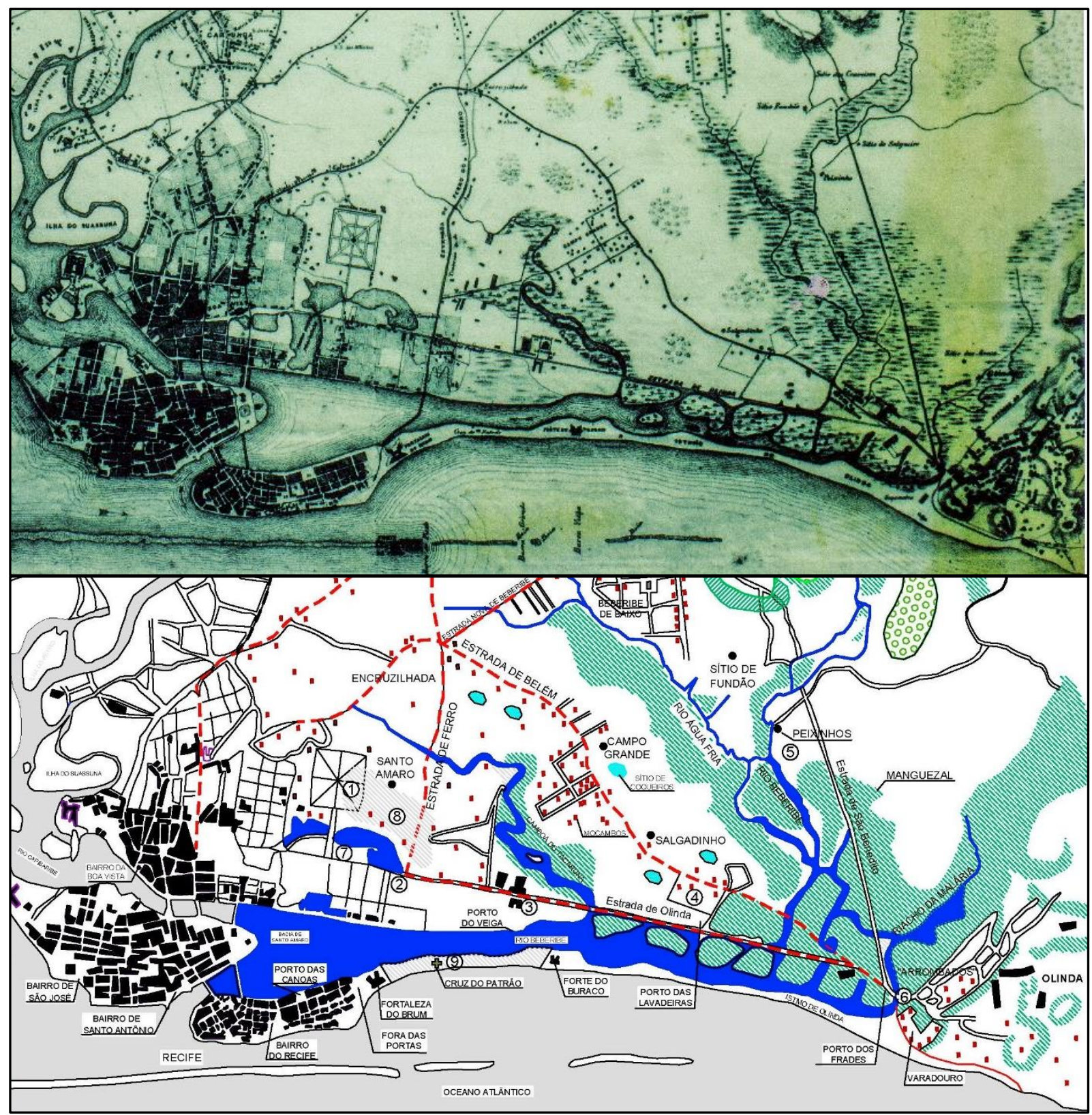

Figura 04: Pormenor da ocupação do baixo Beberibe entre as cidades do Recife e de Olinda no final do século XIX - trecho entre o bairro do Recife e o Varadouro (Planta da Cidade do Recife e seus arrabaldes - 1876). Além da localização de bairros, freguesias, fortalezas, portos, istmo, manguezal, estradas, mocambos, sítios, ilhotas, rios, riachos, entre outros objetos, vide o esquadrinhamento médico-higienista na sequência numeral entre 1 a 9: 1 Cemitério de Santo Amaro (1851); 2 - Cemitério dos Ingleses (1814); 3 - Asilo da mendicidade - 1872 (Hospital dos Lázaros - 1761) ; 4 - Usina Beltrão (Fábrica Tacaruna); 5 - Matadouro de Peixinhos; 6 - Antiga represa do Varadouro (demolida em 1856); 7 - Padarias e oficinas em Santo Amaro (1842); 8 - Espaço de quarentena do tráfico (século XVII ao XIX); 9 Cemitério de cativos pagãos (século XVII ao XIX).

Desenho: Bruno Maia Halley / André Pereira Marinho. (Autocad Map 3D 2014). 


\section{Meandros finais: as molduras arruinadas de um espaço marginal}

O baixo Beberibe percorre mais de uma dezena de quilômetros. Após receber as águas do rio Morno, seu principal afluente, atravessa as colinas entre o Recife e Olinda, nas imediações do bairro de Beberibe, penetrando na várzea da planície de inundação, alargando-se até o litoral (CAMPOS, 1991). Já próximo à costa, avolumase com as águas do riacho Lava-Tripas, e depois, com o manancial do rio Água Fria, seguido pelo riacho da Malária, no sopé de Olinda, onde inclina um meandro na direção meridional rumo ao Recife. Como uma serpente, entre mangues, ilhotas, charcos, baixios e bancos de areia, margeia a restinga e as terras do Tacaruna, até abraçar o Capibaribe, na bacia de Santo Amaro. Na boêmia de suas águas, os rios desaguam conjuntamente no Atlântico, no porto do Recife.

Entre os séculos XVII e XIX, essa moldura líquida assistira uma ocupação rarefeita entre os núcleos habitáveis de Olinda e do Recife, singularizando-se por certos objetos, usos e eventos, especialmente os de ordem médico-higienista. No trabalho ora descrito, reconstituiu-se parte desta geohistória a partir dos eventos em torno da represa do Varadouro e da atividade dos canoeiros. A água represada, o pântano e as canoas representaram traços indissociáveis da memória estigmatizada do Beberibe, conformando, junto aos cemitérios de cativos, as barracas de quarentena do tráfico, e, tempo depois, os objetos propriamente do higienismo - hospitais, asilo, cemitérios, matadouro e fábrica - um "espaço marginal" às suas margens e meandros.

$\mathrm{Na}$ ordem do dia, parte significativa desta memória encontra-se soterrada, encoberta por outras histórias inerentes à expansão urbana do Recife e de Olinda. Há poucos indícios da antiga represa do Varadouro e nenhuma referência sobre a existência dos canoeiros, tampouco do Porto das Canoas, embora ainda haja alguma atividade náutica no baixo Beberibe (jangadeiros, barqueiros e pescadores). O único monumento sobrevivente deste período é a Cruz do Patrão, quase invisível em sua estrutura, pelas instalações sucateadas do porto do Recife. Os cemitérios dos "brancos" e hospitais permanecem, enquanto outras ruínas teimam em sobreviver em seus escombros, como o Matadouro de Peixinhos e a Usina Beltrão, no Tacaruna. Os antigos espaços da escravidão continuam esquecidos, abandonados e aterrados por outras construções. 
De certo modo, as margens do baixo Beberibe caracterizam-se por molduras arruinadas, marcadas por resquícios de manguezal contaminado e por hiatos territoriais pontilhados por construções desocupadas e/ou desprezadas (vide as ruínas da Fortaleza do Buraco). Afora isso, aqui e acolá, emanam segregações espaciais, zonas de pobreza, prostituição, tráfico e consumo de drogas, camufladas por modernos equipamentos, que tentam escamotear a desigualdade social existente (como no caso do extenso muro do Shopping Tacaruna que tenta "esconder" a penúria comunitária de Santo Amaro). Consequentemente, o caráter marginal e segregador do Beberibe mostra-se contínuo no tempo e no espaço, inclusive em alguns dos seus topônimos, que rememoram eventos e usos negativos, como Malária e Lava Tripas, nomes de riachos que evocam identidades territoriais alusivas a um "espaço doentio", alvo de campanhas médicas e de delimitações higienistas entre o século XVII e o final do XIX.

\section{REFERÊNCIAS}

ABREU, M. "Pensando a cidade no Brasil do passado". In: SILVA, J. B. (Org.). A cidade e o urbano: temas para debates. Fortaleza: EUFC, 1997.

AGRA, V. (Coord.). Projeto Foral de Olinda. Olinda: Prefeitura Municipal de Olinda, 1996. ANDRADE, G. O. A cólera-morbo - um momento crítico da história da medicina em Pernambuco. 2a ed. Recife: Editora Massangana - FUNDAJ, 1986.

ANDRADE, G. O. de Montebelo, os males e os mascates. Recife: Editora Universitária/UFPE, 1969.

ANNAES da Medicina Pernambucana, 1842-1844. Recife: Secretaria de Educação e Cultura, 1977 (reedição Fac-similar, 1843-1844).

ARAÚJO, R. de C. B. de. As praias e os dias: história social das praias do Recife e de Olinda. Recife: Fundação de Cultura Cidade do Recife, 2007.

CABRAL, A. A. C. Os gestores públicos e suas ações no bairro de Campina do Barreto: o vivido e o instituído. Dissertação (Mestrado em Geografia) - Centro de Filosofia e Ciências Humanas, Universidade Federal de Pernambuco, Recife, 2004.

CAMPOS, H. L. A bacia hidrográfica do Beberibe: um enfoque ambiental. Dissertação (Mestrado em Geografia) - Centro de Filosofia e Ciências Humanas, Universidade Federal de Pernambuco, Recife, 1991.

CARVALHO, M. J. M. de. Liberdade - rotinas e rupturas do escravismo no Recife, 18221850. Recife: Editora Universitária, 2010.

CARVALHO, M. J. M. de. "O quilombo de Malunguinho, o rei das matas de Pernambuco". In: REIS, J. J.; GOMES, F. dos S. (Orgs.). Liberdade por um fio: história dos quilombos no Brasil. São Paulo: Companhia das Letras, 2011.

CARVALHO, M. J. M. de. Os caminhos do rio: negros canoeiros no Recife na primeira metade do século XIX. Afro-Ásia, Salvador, n. 19/20, 1997, p. 75-93.

CASTRO, J. de. Documentário do Nordeste. São Paulo: Brasiliense, 1968. 
CORREIA DE ANDRADE, M. C. "Formação da aglomeração recifense". In: JATOBÀ, L. (Org.). Estudos nordestinos sobre crescimento urbano. Recife: FUNDAJ, 1987, p. 257292.

COSTA, F. A. P. da. Anais pernambucanos (vols. 4 e 10). 2. Ed. Recife: FUNDARPE, 1983.

DANTAS SILVA, L. O Recife - imagens da cidade sereia. Recife: Prefeitura da Cidade do Recife, Comunigraf Editora, 1998.

DARWIN, C. "A muralha de pedra". In: DANTAS SILVA, L.; MAIOR, M. S. (Orgs.). O Recife quatro séculos de sua paisagem. Recife: Editora Massangana, 1992, p. 163-166.

DUARTE, E. "O tratado único da constituição pestilencial em Pernambuco. Estudo crítico por Gilberto Osório de Andrade". In: MORÃO, ROSA e PIMENTA. Notícia dos três primeiros livros em vernáculo sobre a medicina no Brasil. Estudo crítico de Gilberto Osório de Andrade. Introduções históricas, interpretações e notas de Eustáquio Duarte. Prefácio de Gilberto Freyre. Pernambuco: Arquivo Público Estadual, 1956.

FREITAS, O. Medicina e costumes do Recife antigo. Recife: Imprensa Industrial, 1943. GAMA, J. B. F. Memórias históricas da província de Pernambuco. Vol. II. Tomo IV. Recife, 1972.

GRAHAM, M. "O Recife em tempo de revolução". In: DANTAS SILVA, L.; MAIOR, M. S. (Orgs.). O Recife - quatro séculos de sua paisagem. Recife: Editora Massangana, 1992, p. 121-142.

HALLEY, B. M. Catimbolândia: tramas negras do xangô na Veneza Americana - arredores do rio Beberibe (Recife, 1867-1945). Tese (Doutorado em Geografia) - Instituto de Geociências, Universidade Federal Fluminense, Niterói, 2017.

HALLEY, B. M. Dos moinhos de açúcar aos sítios de arrabaldes: a formação dos bairros continentais na cidade do Recife. Revista de Geografia (UFPE), Recife, n. 3, 2013, p. 58-81. JUCÁ, G. N. M. A implantação de serviços urbanos no Recife: o caso da Companhia do Beberibe (1838-1912). Dissertação (Mestrado em História) - Centro de Filosofia e Ciências Humanas, Universidade Federal de Pernambuco, 1979.

KOSTER, H. Viagens ao Nordeste do Brasil. São Paulo: Nacional, 1942.

MELLO, E. C. de. "Canoas do Recife". In: DANTAS SILVA, L.; MAIOR, M. S. (Orgs.). 0 Recife - quatro séculos de sua paisagem. Recife: Editora Massangana, 1992, p. 193-226. MELO, M. L. de. Metropolização e subdesenvolvimento: o caso do Recife. Recife: $\mathrm{CFCH}-$ DCG/UFPE, 1978.

MORÃO, ROSA \& PIMENTA. Notícia dos três primeiros livros em vernáculo sobre a medicina no Brasil. Estudo crítico de Gilberto Osório de Andrade. Introduções históricas, interpretações e notas de Eustáquio Duarte. Prefácio de Gilberto Freyre. Pernambuco: Arquivo Público Estadual, 1956.

OUTTES, J. O Recife pregado à cruz das grandes avenidas - contribuição à história do urbanismo (1927-1945). Dissertação (Mestrado em Desenvolvimento Urbano) - Centro de Artes e Comunicação, Universidade Federal de Pernambuco, Recife, 1991.

ROCHA, L. A. História da medicina em Pernambuco (séculos XVI, XVII e XVIII). Recife: Arquivo Público Estadual, 1960.

SANTOS, M. Metamorfoses do espaço habitado. São Paulo: Hucitec, 1988.

SETTE, M. Maxambombas e maracatus. 4 ed. Recife: Fundação de Cultura da Cidade do Recife, 1981.

SILVA, M. G. B. da. Grandes empreendimentos: as modernizações e a reconfiguração territorial promovida entre os centros urbanos do Recife e Olinda. Dissertação (Mestrado em Geografia) - Centro de Filosofia e Ciências Humanas, Recife, 2000. 


\section{NOTAS DE AUTOR}

\section{CONTRIBUIÇÃO DE AUTORIA}

Bruno Maia Halley - Concepção. Coleta de dados, Análise de dados, Elaboração do manuscrito, revisão e aprovação da versão final do trabalho

\section{FINANCIAMENTO}

Não se aplica.

\section{CONSENTIMENTO DE USO DE IMAGEM}

Não se aplica.

\section{APROVAÇÃO DE COMITÊ DE ÉTICA EM PESQUISA}

Não se aplica.

\section{CONFLITO DE INTERESSES}

Não se aplica.

\section{LICENÇA DE USO}

Este artigo está licenciado sob a Licença Creative Commons CC-BY. Com essa licença você pode compartilhar, adaptar, criar para qualquer fim, desde que atribua a autoria da obra.

\section{HISTÓRICO}

Recebido em: 06-08-2018

Aprovado em: 01-05-2019 